\title{
1. European Union human rights law: the dynamics of interpretation and context
}

\section{INTRODUCTION}

This book examines the human rights jurisprudence of the courts of the European Union (EU). Its aim is to reveal the character of EU human rights law as shaped by the dynamics of judicial interpretation and its context. Its main contention is that EU human rights law is defined by the interpretative practices of EU courts adopted with reference to its broader and narrower constitutional and governance environment in the EU. The prevalent interpretative practices are responsible for a complex body of human rights law which pursues a busy, multi-tiered constitutional, governance and political agenda. Governed predominantly by functional and instrumental impulses, the law of human rights in the EU follows interpretative considerations and observes limitations which emerge from its context and which are essential for both the lawful and the effective operation and development of the EU polity and its legal order.

Human rights law in the EU is mainly the achievement of judicial interpretation. The constitutional principle that EU legislation and administrative action should be subjected to human rights requirements, the EU human rights principle, and the subsequent extension of this principle to the activities of the Member States, were the creation of the EU judiciary. The institution of a human rights framework for the EU followed from the judicial realization that the EU constitutional architecture was incomplete and that in order for the law to fulfil the central role designated to it in the process of European integration it needs to adhere to the rule of law, in particular, by offering protection to human rights. This inherently functional purpose for human rights and their instrumental use in the constitutional evolution of the EU polity were supplemented by further functionally oriented interpretative considerations which frame human rights law as being responsive to the context of law and governance in the EU. From the early days, the EU human rights jurisprudence has consciously taken into 
account interpretative considerations which link the protection of human rights to its context. These include considerations such as the effectiveness of EU governance and administration, the effective enforcement of EU law in particular, entrusting national courts with roles in the application of EU law and designating their position in the multi-layered EU judicial system and their role in the application of EU law, or maintaining the integrity of EU legislation and of the corresponding governance structures, especially by observing the compromise achieved in EU instruments between the protection of human rights and the competing regulatory objectives or competing human rights. This entanglement in judicial interpretation of the jurisprudence with the constitutional agenda of the EU polity and with broader issues linked to EU regulatory, administrative and judicial activity and its effectiveness, and the resulting complexity of the jurisprudence are the most fundamental characteristics of the law of human rights of the EU.

The genesis and development of EU human rights law is a frequently retold story in European legal studies. The legal principles developed by the EU Court remain attractive for legal research even today, predominantly because of the exposure of the jurisprudence to the broader agenda of constructing an EU polity which is endowed with sufficient constitutional qualities. Our interest was also raised by EU courts interpreting human rights with reference to their broader functions in the EU polity. This constitutional feature prompted our more extensive and detailed investigation in this book into the connections between judicial interpretation and the EU constitutional and governance context in this segment of EU public law. Building on the premise that the relevant interpretative practices of EU courts reflect on the EU constitutional and governance context, we examine how its broader and narrower context has influenced the judicial introduction of a human rights language into EU law, the definition of the scope of human rights in the EU, the calibration of judicial deference in the application of human rights in the EU, the judicial balancing between competing rights and interests, and generally the position of human rights in the EU constitutional order and in the EU polity. Mainly, we are interested in the character of the law of human rights in the EU and also in the interpretative considerations which influence and shape that character. It is hoped that our book reveals the underlying interpretative dynamics of the EU human rights jurisprudence and sheds light on the considerations which drive judicial interpretation in the different environments in which human rights issues are raised in EU law.

The exposure of the human rights jurisprudence to the agendas of the EU polity and to considerations arising from the context of EU law and 
governance suggests a complex body of law. Its assessment requires looking at the interpretative practices followed by EU courts and examining the choices and influences driving them. Identifying and examining these enable capturing EU human rights law in its complexity and projecting an image for the jurisprudence in which what otherwise could be regarded as incompleteness and incoherence in the protection of human rights are explained as consequences of consciously crafted and constitutionally sound interpretative responses from EU courts. Understanding the complexity of the relevant interpretative practices is a necessary condition for locating the position of human rights in the EU polity and for a balanced characterization of the jurisprudence. We argue in this book that the functional character and the ambitious uses of human rights are complemented by conventional conceptualizations and applications of human rights before EU courts. The line of inquiry suggested here resonates with the opinion formulated a while ago that assessments of the role of human rights in the EU must address its complexity which follows from the character of the different rights protected, the actual contexts in which human rights are invoked and their different features, and the actual place and impact of the human right invoked in that particular environment. ${ }^{1}$

The complexity of EU human rights law as developed by the interpretative practices of EU courts and the perspectives it provides for the characterization of the jurisprudence are perhaps most visibly illustrated in the interplay between the rule of law and human rights in the EU. As will be discussed in detail in Chapter 2, the EU human rights principle is a direct manifestation of the rule of law and its character should reflect the character of the EU's rule of law principle. Its basic definition that human rights must be observed by the EU institutions in their activities mirrors the substance traditionally associated by EU courts in judicial interpretation with the rule of law. The crammed constitutional, governance and political agenda acquired by the rule of law in the EU polity is regarded as responsible for the complex character and the multiple applications of human rights in the jurisprudence. The relevance of considerations arising from the broader legal and governance context in the interpretation of human rights before EU courts follows from the relevance of the same considerations for the interpretation and application of the rule of law principle in the EU, and the limitations of the

1 Gráinne de Búrca, 'The Language of Rights and European Integration' in Jo Shaw and Gillian More (eds), New Legal Dynamics of European Union (Clarendon 1995) 53. 
human rights jurisprudence and of the involvement of EU courts in the protection of human rights follow from the limitations of the rule of law and of the related judicial functions. The influences also work in reverse. The interpretation of human rights in a particular interpretative context, for instance the interpretation of the right to effective judicial protection in the context of the multi-layered EU judicial system, endows the rule of law with a meaning particular to the EU polity and requires the rule of law to acknowledge the particular agenda driving the human rights jurisprudence.

The relevance of the constitutional and governance context in the interpretation of human rights can be observed from the early, formative period of EU human rights jurisprudence. The first judgments establishing the EU human rights principle pursued the co-related agendas of securing the autonomy of the EU legal order and establishing its harmonious relationship with domestic constitutional orders. In line with the general character of the EU Court's pioneering constitutional jurisprudence, these judgments following the objective of policy effectiveness and the related priority of securing Member State compliance with EU obligations, regarded law from the perspective of its functions in European integration. In these rulings, human rights were used as instruments which beyond their immediate application in adjudicating challenges against EU action or against the conduct of the Member States fulfil a strategic role in the effective operation and overall development of the EU polity. They emerged as a genuine 'existential requirement' 2 for the EU polity which ensure that individuals receive legal protection and public powers are subjected to restraints, that the EU is better governed and administered and that the constitutional qualities of the EU legal order and the legitimacy of EU action are reinforced.

In the following sections, we will establish the conceptual foundations of our examination of more than five decades of human rights law in the EU. We revisit previous accounts and characterizations of the jurisprudence, and building from that we establish what we hope is a comprehensive framework for investigating the interpretative practices of EU courts and the interpretative considerations arising from the EU constitutional and governance context which drive the human rights jurisprudence. We will commence this introductory chapter with discussing what is known and what we want to reveal about the character of human rights law in the EU, then move onto the introducing the most relevant

2 Cited from Opinion of Advocate General Maduro in Case C-380/05 Centro Europa 7 [2005] ECR I-0349, para. 19. 
interpretative considerations and interpretative environments of the jurisprudence, which will be examined in detail in subsequent chapters, and close the chapter by discussing our fundamental question what character has been achieved for EU human rights as a result of the interplay between context and judicial interpretation.

\section{THE CHARACTER OF HUMAN RIGHTS LAW IN THE EU}

The functional character of EU human rights law and the exposure of the EU human rights jurisprudence to considerations arising from the broader context of European integration have long been acknowledged in legal commentary. In examining the origins of the judicial protection of human rights in the EU, they recognized the protection of human rights as an instrument introduced to secure the acceptance of the supremacy principle in the Member States and also as a response to the challenges based on domestic constitutional principles against the autonomy of the EU legal order. ${ }^{3}$ Protecting human rights in the EU was a judicially engineered solution to relieve the pressure arising from the 'divided sovereignty' 4 between the EU polity and the Member States and an 'act of self-preservation' 5 for the emerging supranational sovereign that we now call the European Union. Arguably, it served the broader agenda of furthering legal integration in Europe ${ }^{6}$ and it was inspired in part by concerns for the effectiveness of the EU legal order and part by other pragmatic considerations of governance at the European level. ${ }^{7}$

3 Inter alia Joseph H.H. Weiler, 'Fundamental Rights and Fundamental Boundaries' in Nanette A. Neuwhal and Allan Rosas (eds), The European Union and Human Rights (Kluwer 1995) 107-108; Alec Stone Sweet, 'Constitutional Dialogues in the European Community' in Anne-Marie Slaughter, Alec Stone Sweet and Joseph H.H. Weiler (eds), The European Court and National Courts (Hart 1998) 317-319; Pierre Pescatore, 'Written Communication "The Protection of Human Rights in the European Communities" (1972) 9 CMLRev 73, 74-75.

4 Trevor C. Hartley, 'Federalism, Courts and Legal Systems: The Emerging Constitution of the European Community' (1986) 34 AJCL 229, 243.

5 Maurice H. Mendelson, 'The European Court of Justice and Human Rights' (1981) 1 YEL 125, 130.

6 Jason Coppel and Aidan O’Neil, ‘The European Court of Justice: Taking Rights Seriously?' (1992) 29 CMLRev 669, 670.

7 Francis G. Jacobs, 'The Evolution of the European Legal Order' (2004) 41 CMLRev 303, 309. 
While these original rationales remain relevant in defining the character of EU human rights law and already indicate how the broader European context have played a role on the construction of that body of law by means of judicial interpretation before EU courts, this book aims to generate a more complex and as a result a more balanced image of the EU human rights jurisprudence as influenced by concrete and rather nuanced interpretative considerations arising from the context of EU law and governance. We adhere to Douglas-Scott's explicit claims that the jurisprudence suggests a manipulation of human rights for purposes other than their protection ${ }^{8}$ and an introduction of 'ulterior agendas'9 into judicial interpretation, and that human rights law is exploited to support the expansion of EU governance into new areas. ${ }^{10}$ Faithful to our aims, we, however, intend to penetrate deeper in defining the character of EU human rights law and provide a more detailed account of the impact of the interplay between context and interpretation on the jurisprudence. By investigating and recognizing the complexity of the EU human rights jurisprudence, we aim to tease out further layers from the otherwise attractive metaphor of human rights in the EU being a 'floating concept' open to all application and interpretation which may follow from its context. ${ }^{11}$ It may be evident by now that we do not regard the presence of a broader agenda and the complex influences of the context on the jurisprudence a necessarily negative development.

Protecting the autonomy and supremacy of EU law provides only a partial explanation for the judicial protection of human rights in the EU. ${ }^{12}$ Such an account represents the concerns of a particular period of EU constitution-building which eventually led to the completion of a constitutional trinity for the EU consisting of the principles of supremacy and direct effect and the EU human rights principle, all recognized in the jurisprudence to support the autonomy of the emerging constitutional order. As Williams argued, the recognition of human rights as a condition

8 Sionaidh Douglas-Scott, 'The European Union and Human Rights after the Treaty of Lisbon' (2011) 11 HRLR 645, 650.

9 Borrowed from Sionaidh Douglas-Scott, 'Fundamental Rights in the EU: the ambiguity of judicial review' in Tom Campbell, Keith D. Ewing and Adam Tomkins (eds), The Legal Protection of Human Rights (OUP 2011) 289.

10 ibid.

11 Sionaidh Douglas-Scott, Constitutional Law of the European Union (Pearson 2002) 434.

12 See de Búrca (n 1) 39. 
of the validity of EU measures was crucial in the process of 'authenticating' the EU as a site of governance. ${ }^{13}$ Arguably, the minimalism which characterized the early, foundational case law ${ }^{14}$ indicates less an unqualified judicial embrace of a human rights agenda, but rather a calculated judicial response which acknowledged a commitment to the protection of human rights with the purpose of safeguarding the constitutional building-blocks of European integration.

Securing the autonomy of the EU legal order was recognized as the motivation for the judicial protection of human rights in the EU in the famous passage in Internationale Handelsgesellschaft which contended that EU law may only be subjected to its own legality requirements and taking into account constitutional requirements at the national level would jeopardize its integrity. ${ }^{15}$ Opinion 2/94 formulated the same arguments, this time in relation to the ECHR, in a more delicate manner and placed emphasis primarily on the constitutional significance and implications of introducing substantial changes externally to the system of human rights protection in the EU. ${ }^{16}$ The constitutionally defining choice between EU and international human rights law in Kadi was also made with reference to maintaining the integrity of the constitutional principles of EU law. ${ }^{17}$ The autonomy of the EU legal order was a central component in the Strasbourg court's assessment of the protection of human rights in the EU in Bosphorus, discussed in detail in Chapter 8, which regarded sustaining the legal and other achievements of the EU as a form of regional integration of states as supporting the discretion granted for the EU institutions in the protection of Convention rights. ${ }^{18}$ The treatment of ECHR law in the EU jurisprudence, examined in the same chapter, has followed the agenda of enhancing the autonomy and legitimacy of the EU legal order and the protection of human rights in the EU.

\footnotetext{
13 Andrew Williams, EU Human Rights Policies (OUP 2004) 129.

14 Ian Ward, A Critical Introduction to European Law (Butterworths 1996) 140.

15 Case 11/70 Internationale Handelsgesellschaft [1970] ECR 1125, para. 3. According to Tridimas, this followed from the Treaties and enabled the Court to assure the Member States that the Treaty they had signed complies with the rule of law, Takis Tridimas, The General Principles of EU Law (OUP 2006) 302.

16 Opinion 2/94 Accession by the Community to the European Convention for the Protection of Human Rights and Fundamental Freedoms [1996] ECR I-1759, paras 32-35.

17 Joined Cases C-402/05 P and C-415/05 P Kadi [2008] ECR I-6351, especially para. 285 .

18 Bosphorus v Ireland ECHR 2005-VI, paras 150-151 and 155-156.
} 
The introduction of a human rights principle in the process of constructing a constitutional identity and a legal order suited for the ambitious supranational polity, nevertheless, necessarily entailed a human rights agenda - no matter how limited - for the EU. The new constitutional principles generated legal changes within the polity which required a response from the EU Court, the architect of the new legal order, to keep the polity under control. ${ }^{19}$ The EU human rights principle was prompted by the 'arrogation of power' to the EU which resulted from the judicial creation of power-shifting doctrines, such as supremacy, direct effect and implied powers, and which indicated that the use of powers acquired by the EU will not be limitless. ${ }^{20}$ The necessity for the legal containment of newly found EU powers, as rationale for the protection of human rights, was recognized in the judgments in Nold and Hauer ${ }^{21}$ in the judicial principle, which was also reiterated in Opinion 2/94 concerning the accession of the EU to the ECHR, that respect for human rights is a condition for the legality of EU measures and that their observance must be enforced. ${ }^{22}$ The political endorsement of the principle was achieved in the 1977 Joint Declaration laying down a commitment for the institutions of the European Communities to respect human rights in the exercise of their powers and in pursuance of the aims of the EU in general. ${ }^{23}$ The principle was later elevated to constitutional status by virtue of ex Article 6 TEU (now Article 6 TEU) furnishing the EU institutions with binding constitutional boundaries for their conduct and offering a constitutional basis for the jurisdiction of EU courts to enforce human rights.

19 See Philip Alston and Joseph H.H. Weiler, 'An 'Ever Closer Union' in Need of a Human Rights Policy: The European Union and Human Rights' in Philip Alston (ed) The EU and Human Rights (OUP 1999) 22-23.

20 Joseph H.H. Weiler, 'The Transformation of Europe' (1991) 100 YLJ 2403, 2417. Tridimas saw the EU human rights principle as a concession granted to national sovereignty on the road to secure the legitimacy of the EU polity which kept the EU Court in control over the constitutional qualities of the EU legal order, Tridimas (n 15) 304.

21 Case 4/73 Nold [1974] ECR 0491, para. 13; Case 44/79 Hauer [1979] ECR 3727, para. 15.

22 Opinion 2/94, paras 33-34; C-402/05 P and C-415/05 P Kadi, para. 285.

23 Joint Declaration by the European Parliament, the Council and the Commission concerning the Protection of Fundamental Rights and the European Convention for the Protection of Human Rights and Fundamental Freedoms, OJ 1977 C 103/1, para. 2. 
The EU human rights principle was presented as a consolidating principle for the emerging EU polity, and offered an institutional recognition of the rule of law as a foundational principle for the new legal order. It allowed the jurisprudence to interpret human rights as instruments capable of both supporting the constitutional foundations of the new legal order and containing the new legal order by formulating institutional duties and institutional constraints for the process of European governance. The Court in Kadi made it particularly clear that the judicial protection of human rights is a constitutional fact, a cornerstone of EU constitutionalism which must not be compromised. ${ }^{24}$ It made the protection of human rights 'integral, inherent, transverse' in the functioning of the EU polity, which should form part of all objectives, functions and powers of the EU, ${ }^{25}$ and opened the gate for general constitutional changes affecting accountability and responsibility in the EU and anchored judicial review on the legal and institutional map of the EU. EU human rights law, together with other components of the rule of law, gave shape to the EU legal order and European governance. This was seen as human rights providing a certain, limited public morality for the EU. ${ }^{26}$

The original rationales for the protection of human rights were subsequently supplemented by further motivations. These had similar relevance for the broader context of European integration-building and reinforced the functional character of human rights in the EU polity. The gradual consolidation of the jurisprudence and the more confident use of human rights law, often borrowed from other jurisdictions, such as the ECHR, indicated a modified relationship between individuals and the EU institutions and that the EU was prepared to embrace the benefits, such as broader legitimacy and a more appreciative political audience, which follow from a higher quality and better supported constitutional jurisprudence. The protection of human rights was an essential prerequisite of anchoring the legal construct of EU citizenship which aimed at creating a new form of constitutional and political identity so far missing from the maturing EU constitution. Human rights found explicit utility as constitutive agents and not simply as negative instruments providing defences against challenges to the emerging legal order. This is now reflected in the Treaty provisions (Article 6 TEU) which mention human rights

24 C-402/05 P and C-415/05 P Kadi, para. 322.

25 Joseph H.H. Weiler and Sybilla C. Fries, 'A Human Rights Policy for the European Community and Union: The Question of Competences' in Philip Alston (ed.) The EU and Human Rights (OUP 1999) 155-156.

26 See Ian Ward, 'Beyond Constitutionalism: The Search for a European Political Imagination' (2001) 7 ELJ 24, 25. 
among the values of the EU polity and their protection as a shared commitment among the Member States.

There is no need for us to give a detailed account of the constitutional rationales for the protection of human rights in the EU. It is sufficient that we recognize that the jurisprudence has been exposed to interpretative considerations arising from its broader context and human rights have been interpreted as having particular functions in the construction of the emerging legal and constitutional order since the conception of the EU human rights principle. The character of the human rights jurisprudence is visible from the judicial declarations designating a place and a role for human rights in EU law, such as in Internationale Handelsgesellschaft and more dramatically in Hauer, ${ }^{27}$ which link the protection of human rights to the autonomy of the EU legal order and to the supremacy principle and also to further considerations arising from these principles, the uniformity and the effectiveness of the law in the EU in particular. The reasoning of the Court confirms that the protection of human rights is by design attached to the role that law was destined to play in European economic and political integration and that its interpretation will reflect the needs of the particular legal and governance environment. The Court in Internationale Handelsgesellschaft hinted at this specifically when stating that the protection of human rights 'must be ensured within the framework of the structure and objectives of the Community.'28

Examining the rationales for the protection of human rights in the EU allows another important remark. Despite the overwhelming impact of the broader context of European integration on the law, human rights in the EU are applied and interpreted to perform functions normally expected from human rights law. They constrain legislative and administrative action in the EU, contribute to the system of legal accountability and offer a protected legal position for individuals. They enable fair administrative and judicial procedures, contribute to a more equal EU polity and ensure the protection of certain values in the predominantly economic law of the EU. The EU human rights principle makes a commitment that human rights are protected which should not be left out of account when evaluating the human rights law of the EU. Any criticism addressing the diverse agendas served by the human rights jurisprudence and the influence of specific considerations arising from

27 11/70 Internationale Handelsgesellschaft, para. 3; 44/79 Hauer, paras $13-14$.

${ }_{28}$ 11/70 Internationale Handelsgesellschaft, para. 4. Identified as 'controlling factors' in the jurisprudence, Mendelson (n 5) 152. 
the context of EU law and governance on the interpretation of human rights can be contrasted with the EU courts recognizing and protecting human rights in their jurisdiction. This unchallengeable fact renders the critical evaluation of the human rights jurisprudence particularly difficult, as it will be demonstrated throughout this book.

The constitution of EU human rights law provides further indications that the law and its interpretation are driven, although not exclusively as indicated in the preceding paragraph, by considerations following from the broader context. Human rights in the EU are categorized as general principles of law. Their invention in EU law as general principles was, the EU Court lacking other legal options, a 'solution de dépannage' which according to the late Pierre Pescatore, one of the founding fathers of the EU legal order and EU human rights law, enabled the EU judiciary to fulfil its functions with a 'broad view of its mission'. ${ }^{29}$ It offered the best of two worlds for the Court; the ready availability of human rights to consolidate the EU constitutional order and flexibility to interpret and apply human rights 'in the best interest of the Community'. ${ }^{30}$ The broader utility of the form selected for human rights in the EU is clearly represented in the recent judgments in Mangold and Kücükdeveci where the legal limitations on the justiciability of rights derived from EU legislation were surpassed by making the equivalent general principle of EU law available for individuals to pursue their claims before national courts effectively. ${ }^{31}$

Human rights as general principles of law have, using the expression coined by Miguel Maduro, a 'double constitutional life' 32 in the EU. They contributed to the consolidation of the EU constitutional order by offering stability and restraint, in particular, by introducing a rights language and an avenue of control of EU legislative and administrative action. They filled gaps in the EU constitutional framework and offered solutions when common principles were needed to be developed for EU governance and administration. Their flexibility, however, also enabled human rights to contribute to the construction and development of the EU

29 Pescatore (n 3) 79.

30 Akos G. Toth, 'The European Union and Human Rights: the Way Forward' (1997) 34 CMLRev 491, 492.

31 Case C-144/04 Mangold [2005] ECR I-9981, paras 75-78; Case C-555/07 Kücükdeveci [2010] ECR I-0365, paras 50-51.

32 Borrowed from Miguel P. Maduro, 'The Double Constitutional Life of the Charter of Fundamental Rights of the European Union' in Steven Peers and Angela Ward (eds), The EU Charter of Fundamental Rights (Hart 2004) 271-272. 
polity and accommodate demands arising in the process of European integration. EU courts interpreted human rights to give expression to the legal and governance considerations of the broader context. The homegrown right to effective judicial protection indicates that in the EU constitutional order the use of public powers is subject to judicial scrutiny and individuals may vindicate their rights before courts of law. It, however, also serves as the basis of the system for the effective enforcement of EU law in the Member States and, beyond the immediate concern of Member State compliance, it is interpreted having regard to the institutional needs of the EU's multi-layered judicial system consisting of the Luxembourg court and national courts. The right to effective judicial protection as a general principle of law is linked both to the narrower constitutional role of human rights in the EU and to considerations arising from the context of effective EU governance and the effective participation of national courts in the application of EU law.

The relationship between the different, conventional and unconventional uses of human rights is not without conflict. Their contribution to polity-construction and their interpretation in the context of the progressive application of the law and governance structures may be at odds with their fundamental function of constraining the EU polity and providing protection to the rights of individuals. The EU's own right to effective judicial protection provides an excellent illustration in this regard. As discussed in Chapter 5, the right of access to a court is interpreted subject to the agenda of sustaining and operating the EU's multi-layered judicial system in the course of which private litigants, natural and legal persons have been disadvantaged by being driven to seek access to the EU Court through preliminary references from national courts instead of allowing them direct access to the courts in Luxembourg in actions for annulment. To exonerate its interpretative choice and to make its interpretative construction more complete, the EU Court elected in its jurisprudence to concretize the responsibilities of national courts in ensuring that EU measures suspected of illegality are presented before the EU Court for assessment. In such circumstances, it is inevitable for the jurisprudence to engage in an act of measuring, possibly balancing the competing uses and agendas of human rights law in the EU against each other.

Human rights in the EU in the majority have been and remain judge-made. The adoption of the EU Charter of Fundamental Rights is not expected to transform this fundamental feature of the law. As discussed in Chapter 2, although the EU Charter may reduce the discretion of EU courts in developing their jurisprudence and make them aware of the political nature and the constitutional position of human rights in the EU, its impact could also be the empowering of EU courts 
and the further legitimizing of their human rights jurisprudence. Heavy judicial involvement in the development of human rights law further accentuates the flexibility of human rights as general principles of law and the possibility of the interpretation of human rights being influenced by considerations, found relevant by the EU judiciary aware of the demands and purposes of the EU legal order, which follow from the broader context. There are clear examples of judicially introduced external considerations in EU human rights law, which include the linking of human rights to the autonomy of the EU legal order, the relevance of the effective application and enforcement of EU law for fair trial rights or the judicial borrowing from ECHR law as a dominant interpretative practice. While the judicial administration of human rights law in the EU may leave the law insufficient, ill-defined ancillary and dependent upon the intake of cases, ${ }^{33}$ it may also be evaluated as offering the benefit of a responsive and complex jurisprudence moving together with the evolving polity.

In its endeavours in giving shape to EU human rights law, EU courts are barely constrained by the provisions determining their jurisdiction. Article 19 TEU, stipulating the task for EU courts to ensure that in the application and interpretation of the Treaties the law is observed, is difficult to read as restricting the discretion of the EU judiciary. Rather, it suggests a robust constitutional licence empowering EU courts to address and manage the legal issues emerging in the process of European integration, including the protection of human rights. It provides a central position for judicial power in the constitutional arrangements under the Treaties which allowed EU courts to make the 'judicial leap' of developing a human rights law for the EU polity. ${ }^{34}$ Arguably, Article 19 TEU makes the protection of human rights part of the inherent jurisdiction of EU courts and allows them to engage in what was called the retrospective 'myth building' practices advocating that the EU 'is and always has been founded' on the protection of human rights and human rights protection has always been embedded in the Treaties. ${ }^{35}$ Such self-referential determination of their constitutional role and its boundaries enables EU courts

33 See Alston and Weiler (n 19) 13 and Andrew Williams, 'Taking Values Seriously: Towards a Philosophy of EU Law' (2009) 29 OJLS 549, 551-552.

34 See Joseph H.H. Weiler, 'Eurocracy and Distrust: Some Questions Concerning the Role of the European Court of Justice in the Protection of Fundamental Rights within the Legal Order of the European Communities' (1986) 61 Wash. L. Rev. 1103, 1118.

35 Williams (n 13) Chapter 6, especially 139 and 160. See also Ward (n 26)

25. See especially, C-402/05 P and C-415/05 P Kadi, para. 282. 
to adopt interpretative practices which place their human rights jurisprudence firmly in the context of law and governance in the EU.

The jurisdiction and the judicial role assumed by EU courts in human rights matters is, however, not unlimited. As it will be discussed in detail in Chapter 2 in connection with the rule of law, it is constrained by the parallel constitutional authorities in the EU legal space. The constraint may come from internally - from the constitutional authority of the Founding Treaties, the EU legislature and the EU administration, or from externally - from the constitutional authority of the Member States and of binding international commitments. ${ }^{36}$ It falls onto the jurisprudence to recognize these limitations and define their impact on the human rights jurisdiction exercised by EU courts. Deference to the parallel constitutional authorities is one of the dominant interpretative practices in the EU human rights jurisprudence whereby the interpretation of human rights in individual cases needs to take into account that the assessment of the matter may fall to a different constitutional authority or that it needs to be carried out having regard to considerations arising from the parallel constitutional authority. This may manifest in EU courts refusing to interfere with policy choices reflected in EU legislation, with the balances struck between human rights and competing interests and rights in EU instruments, with decisions serving the effective conduct of procedures, and in trusting the assessment carried out by national authorities under national law and trusting national courts with the task of carrying out the final assessment of interferences with human rights, and also in the conscious practice of assessing interferences with human rights on the basis of the jurisprudence developed by the Strasbourg court.

EU human rights law developing from overlapping constitutional spaces, that of the Member States, the EU and the ECHR, and being understood as a matter of its relations with national constitutional laws and regional human rights law are essential arguments in the discussion on the character of the EU human rights jurisprudence. The interpretation of human rights before EU courts takes place in a multi-layered legal arrangement acknowledged as early as the creation of the EU human rights principle which was developed to secure the autonomy of the EU legal and constitutional order with regards the authority of national

36 The protection of national constitutional identities, as recognized under Article 4(2) TEU, is a constitutional 'counter-limit' for EU law and for EU courts expressly recognized in the Treaties, Leonard F.M. Besselink, 'The Protection of Fundamental Rights post-Lisbon' (FIDE 2012: Topic I General Report) <http:// fide2012.eu/index.php?doc_id=94> accessed 10 May 2013, 47. 
constitutional orders. The EU human rights jurisprudence is destined to seek the approval of other constitutional actors, national constitutional courts and the Court of Human Rights in Strasbourg which manifests most visibly in interpretative practices from EU courts which defer to national constitutional requirements or borrow piously from the Strasbourg jurisprudence. ${ }^{37}$ It is markedly reflected in the obsession of the legal commentary with finding the requisite standard for human rights protection in the EU which would satisfy both European and national constitutional requirements. ${ }^{38}$ As indicated earlier in connection with the interpretative practice of deference to parallel constitutional authorities, this 'relational' character of EU human rights law placed in a multilayered structure for human rights in Europe is a recurring issue and dilemma for judicial interpretation in the entire jurisprudence, as discussed throughout this book, and lends to it a multi-layered character.

There has always been an attraction in describing the development of the EU constitutional order including human rights law as a result of a discursive relationship between the EU and national legal orders based on a dialogue between the EU and national courts. ${ }^{39}$ Wedged between parallel constitutional orders at the European and national levels, it was comforting to illustrate EU human rights law as a product of judicial practices which recognize the demands of the parallel constitutional orders and provide appropriate responses to those demands. It was never convincingly established, however, that EU courts have been equipped with a toolkit which would correspond to the task of generating human rights law in a 'reciprocal relationship' with parallel constitutional orders and that the interpretative tools available, especially the comparative approach, ${ }^{40}$ are suitable to create a human rights law that is not simply

37 See the interpretation by Tridimas of the 'Bosphorus-principle' developed by the Strasbourg court, discussed in detail in Chapter 8 , that it represents the same conditional and reversible endorsement of EU human rights law under the ECHR as that granted by national courts under the respective national constitutional orders, Tridimas (n 15) 352.

38 See only the contrasting opinions of Weiler and Besselink, Weiler (n 3) 106 and 109-110 and Leonard F.M. Besselink, 'Entrapped by the Maximum Standard' 199835 CMLRev 629, 670-678.

39 See Aida T. Perez, Conflicts of Rights in the European Union (OUP 2009) 92-93. Describing it as a bottom-up, 'permanent learning process' inspired by national constitutions, Maduro (n 32), 297-298.

40 It must not be overlooked that the 'comparative method' has its own weaknesses, and it is unclear what outcomes it would produce and whether those outcomes would be suitable for the EU. A purely functionalist comparison will not do justice to the task of exploring common constitutional traditions, and a 
'parasitic' or 'purely derivative' but a result of a genuine constitutional dialogue. ${ }^{41}$ Although the common judicial formula speaks of human rights in the EU following from the common constitutional traditions of the Member States, actual investigations into the common ground among the Member States were seldom carried out and hardly ever in a comprehensive fashion. ${ }^{42}$ With the ever-increasing necessity to adhere to the law of the ECHR, borrowing from ECHR law, which could be regarded as a common point of reference for EU and national laws, ${ }^{43}$ may displace interpretative practices which seek the basis for the jurisprudence in common national traditions.

The conceptual model of a judicial dialogue for the evolution of the EU constitutional order, which in Perez's account underpins the 'normative authority' of EU courts in the creation and interpretation of EU human rights law and provides legitimacy to the jurisprudence, seen as a 'shared outcome' for the benefit of the whole community, by 'argumentative communication based upon the exchange of reasons', ${ }^{44}$ suits the here discussed character of EU human rights law particularly well. It suggests an EU judiciary which is informed of the pressures and considerations arising from the context of European integration and which in the interpretation and development of the law pursues predefined objectives in the service of the integration process. The discursive approach should not be interpreted as EU human rights law automatically reproducing the law from the parallel constitutional orders. Instead, it provides a platform for developing autonomous human rights law for the entire EU polity in a multi-layered structure which recognizes the

genuinely contextual approach may render the comparison unfeasible, especially when the original recommendation by the Advocate General in Internationale Handelsgesellschaft to investigate the 'philosophical, political and legal substratum common to the Member States' is considered.

41 Terms borrowed from Gráinne de Búrca, 'Convergence and Divergence in European Public Law: the Case of Human Rights' in Paul R. Beaumont, Carole Lyons and Neil Walker (eds) Convergence and Divergence in European Public Law (Hart 2002) 132.

42 On the comparative method in the area of human rights law, see Mendelson (n 5) 154-156, who advocated the use of evaluative comparative law selecting the best or most suitable rules, and Ulrich Scheuner, 'Fundamental Rights in European Community Law and in National Constitutional Law' 1975 12 CMLRev 171, 185 who argued that the uniform human rights solution for the EU acceptable to all the Member States cannot be influenced by particular detail and must follow 'the general trend of the evolution of legal prescriptions'.

43 Pescatore (n 3) 79.

44 Perez (n 39) 97 and 109-110. 
pressures arising from that structure and produces interpretative solutions to respond to those pressures. ${ }^{45}$

EU human rights law is the product of interpretative practices from EU courts which beyond utilizing human rights to respond to the direct needs of the European constitutional and political construction, exposed the human rights jurisprudence to the specific legal and governance considerations of the EU polity. It has integrated considerations relating to the EU's own rule of law principle, the effectiveness of EU economic regulation, the regulation of the single market, the balance struck between EU regulatory objectives and human rights, the effective operation of the EU judicial system, the effective enforcement of EU law, the sustainability of multi-layered governance structures and mechanisms in Europe, the relationship between EU human rights law and ECHR law and the above indicated relationship between the different constitutional authorities in the EU constitutional order. The reservation in Internationale Handelsgesellschaft that the protection of human rights must be ensured having regard to the structure and objectives of the EU, it seems, was taken on board by EU courts and defined the character of the jurisprudence.

\section{THE INTEPRETATIVE CONTEXTS OF EU HUMAN RIGHTS LAW}

Having established the character of EU human rights law as being shaped by its context and being driven by functional considerations, we now have to introduce the particular interpretative considerations arising from the context of EU law and governance which dominate the human rights jurisprudence of EU courts, which will be examined in detail in the subsequent chapters. As repeatedly hinted earlier, many of the interpretative considerations address the effectiveness of EU law and of the related governance structures or they deal with the EU judiciary determining the boundaries of its human rights jurisdiction vis-à-vis the internal and external constitutional authorities in the European constitutional space. Indeed, their influences on judicial interpretation amount to two major interpretative reactions: deference and balancing between

45 Weiler argued that the formula asking for 'ideas' common to the constitutions of the Member States, instead of asking for a comparative examination and a reliance on national law, enables the EU Court to develop an autonomous human rights law, Weiler (n 3) 113-114. A similar claim made by Maduro in relation to the relevant provisions of the Charter is discussed in Chapter 2. 
control and effective legislative and administrative action. This also follows from the interpretative principle at the heart of the human rights jurisprudence, proportionality, the application of which in general amounts to the two mentioned judicial reactions. However, it would be a mistake to concentrate only on these two broader categories as their influence in different areas of the jurisprudence yields different interpretative outcomes. For example, deference to the constitutional authority of national courts requires interpretative routes different from the need to defer to the balance established by general regulatory objectives and the protection of human rights by the EU legislator. In the same vein, the effectiveness of EU competition enforcement procedures influences the interpretation of human rights differently from the effectiveness of the protection of rights derived from EU law before national courts.

The way the different interpretative considerations influence the jurisprudence reveals distinct areas of EU human rights law and distinct 'usages' 46 of human rights in the EU. Some interpretative considerations reoccur in the entire jurisprudence, although far from in a uniform manner, such as the EU's rule of law principle and the relationship with ECHR law. Others would be quite specific to the given area of EU human rights law, such as the operation of the EU judicial system and the right to effective judicial protection. Certain interpretative considerations, such as maintaining the integrity of EU regulation of human rights, result in painstaking analyses of whether an appropriate balance was achieved between the human rights involved and the competing interests, while others, such as the relevance of ECHR law for EU human rights law, often lead only to summary reproductions of the relevant Strasbourg case law.

This book in its analysis of the EU human rights jurisprudence distinguishes the following interpretative considerations. The rule of law is introduced in Chapter 2 as the primary interpretative consideration for the entire jurisprudence. The protection of human rights is a manifestation of the rule of law in the EU and it finds its conceptual basis in the EU's rule of law principle. The interpretative relevance of the rule of law is manifold. Its formal aspects find expression in EU courts interpreting and applying human rights to ensure the legality of EU action and to hold actors accountable for the breach of the law. The rule of law is also responsible for the unconventional uses of human rights in the EU polity. Under the general effectiveness requirement of the EU, it pursues multiple, often contradicting agendas in the construction of the EU polity

46 Borrowed from de Búrca (n 1) 31. 
and this is channelled into EU human rights law called to appreciate the functional demands of EU law and governance. The conflicts between the conventional constraining and unconventional constitutive aspects of the rule of law in the EU are matched by the corresponding tensions between the different uses of human rights in the EU. The limitations imposed on the rule of law and on EU judicial power by the existence of the relevant parallel constitutional authorities in the European legal space are recognized in the 'relational' and multi-layered character of EU human rights law.

In Chapter 3, we discuss the interpretative practices followed in the domains of EU direct economic regulation and the law of the single market. In these contexts, the interpretation of human rights addresses the questions of what constitutes appropriate regulation from the EU and under the scope of the law of the single market from the Member States, and in this regard what margin of policy and regulatory discretion should be reserved to them. In both domains, the jurisprudence is characterized by deference to the discretion enjoyed in delivering complex and often contradicting policy priorities. Judicial interpretation is clearly informed of the necessity of preserving the integrity of complex regulatory arrangements. EU courts are preoccupied with determining the legitimacy of judicial interference to enforce requirements following from human rights law regarding the design and quality of regulation at the European and national level. The context of EU regulation is responsible for interpretative considerations which are not uncommon before a court of law engaged in the judicial review of regulatory activity on the basis of human rights protecting private (economic) autonomy.

Chapter 4 examines how the increasing regulatory activity in the EU in the field of human rights law affects the jurisprudence. EU measures regulate the scope and substance of human rights, primarily having regard to competing rights or public interest considerations, and lay down boundaries for state and private conduct by establishing balances between the competing considerations. The interpretation of human rights in the judgments which dealt with challenges against the particular balance struck between the protection of human rights and the competing interests and rights or which addressed the human rights requirements regulated is dominated by deference to the human rights arrangements established by the EU legislator in the relevant instrument. EU courts follow the general scheme and structure adopted in the regulation of human rights or the specific provisions which determine the human rights requirements to be observed. Their assessment stays within the framework provided in the relevant instruments for the balancing exercise 
between the competing rights and interests and respects the compromises established by the EU legislator between the policy and human rights objectives of the measure in question. The interpretative practices of EU courts in the majority surrender to the intent of the EU legislator, although there are significant examples of EU courts assuming jurisdiction to correct the human rights arrangements of EU regulatory instruments. Their interference in such instances, in harmony with the general interpretative attitude characterizing this segment of the human rights jurisprudence, in essence aims at securing that the EU instrument in question and the related governance system can be maintained.

The influence of the EU's specific legal and institutional arrangements for the administration of justice in the multi-layered EU judicial system on the interpretation of the EU's own right to effective judicial protection and remedies is examined in Chapter 5. The complex interpretative considerations arising from this context, made particularly complicated by the complementary relationship between the rule of law and the right to effective judicial protection, resulted in interpretative practices which focus on the alternative avenues of redress available in the EU judicial system, primarily before national courts, in ensuring that the right to effective judicial protection is observed and which concerning the participation of national courts in the EU judicial system attempts to reconcile the interest of effective enforcement of EU law with the autonomy available at the national level for regulating and administering the justice system. Influenced by the legal and institutional issues of its context, the central interpretative consideration for the jurisprudence is how to ensure the participation of national courts in the EU judicial system and how effective judicial protection could be secured before them, having regard to the deference owed of the responsibility and obligations of the Member States in the EU judicial system. The jurisprudence on the right to effective judicial protection reveals how the legal and governance context may be able to introduce a complex agenda under the rule of law, here the effective legal protection of individuals in the multi-layered EU judicial system, into judicial interpretation.

Chapter 6 examines the interpretation of procedural rights and guarantees in two procedures conducted by the European Commission - EU competition enforcement procedures and infringement procedures against the Member States. It discusses how the considerations relating to the effective conduct of the relevant EU procedures and the effective use of the discretion available to the Commission to achieve the effective enforcement of EU law influence the relevant rights and guarantees, the rights of the defence in particular. Under the influence of the narrower and broader procedural context, the jurisprudence in both procedures is 
characterized by the interpretative approach of seeking to reconcile the interest of administrative and broader policy effectiveness and the protection of rights.

Chapter 7 examines the multi-layered character of EU human rights law and the interpretative practices adopted for the protection of human rights in multi-layered legal and governance constructions in the EU. It builds on the discussion of the 'relational' character of the EU human rights jurisprudence provided in Chapters 1 and 2 and it revisits the multi-layered aspects of the jurisprudence discussed in other chapters. The jurisprudence relies on the participation of actors located externally in the protection of human rights in the EU and focuses on the issue of judicial deference owed to the autonomy and discretion of actors at those locations. In the majority of cases, this means the examination of the role of national courts under EU human rights law. Regarding the protection of rights in multi-layered constructions, the main issue is whether all participants should be allowed jurisdiction to control the operation of the system and what institutions and processes are available to maintain its integrity.

In Chapter 8, we consider the influence of the relationship between ECHR law and EU human rights law on the jurisprudence. The two legal orders are joined in a relationship of mutual observation which manifests in interpretative approaches informed of developments in the other legal order. The interpretative considerations arising from the parallel existence of EU and ECHR law affect the entire EU jurisprudence, although not in a uniform manner. They involve the interpretative pressure of divergence from ECHR law, the interpretative reaction of alignment and the interpretative consideration of flexibility, which complement and interact with each other and together shape EU human rights law. The chapter discusses how the human rights jurisprudence of EU courts reacts to the pressure of potential divergences between the parallel legal orders by alignment to ECHR law, which could involve direct borrowing from Strasbourg case law and other less explicit practices of alignment, and that alignment is also necessary in order to exploit the autonomy provided for the development and application of human rights under the flexible ECHR framework, as indicated in the 'Bosphorus-principle' developed by the Strasbourg court. The flexibility offered under ECHR law enables autonomous developments in EU human rights law subject to meeting ECHR requirements, which latter condition makes interpretative practices of alignment necessary. 


\section{A NEW LOOK AT EU HUMAN RIGHTS LAW}

The discussions in this book aim to contribute to the strong tradition of critical evaluation of the EU human rights jurisprudence. The criticisms addressed mainly the pragmatism of judicial interpretation and its openness to the broader agendas of European integration which resulted in an often ambiguous and uneven jurisprudence. It was claimed that the prevalent interpretative practices left only a residual role for the protection of rights ${ }^{47}$ and had failed to locate the place of human rights in the EU polity. ${ }^{48}$ The early critiques of the jurisprudence, disillusioned by the pragmatic ambitions of the EU Court, reprehended especially the instrumental use (the 'manipulation') of human rights 'so as to accelerate the process of legal integration' and maintained that human rights are not protected 'for their own sake' and that the jurisprudence had failed to accord them 'pre-eminent status' ${ }^{49}$ The rebuttal of the latter criticism, which argued that human rights indeed receive adequate protection in the EU, could not avoid admitting that the human rights jurisprudence of the EU may only develop from what is available in the law and as a matter of values and ideology at the different stages of European integration. ${ }^{50}$ This is matched by the claims of a distinctive line of criticism addressing the lack of orientation of EU human rights law. It holds that the EU human rights principle has unclear parameters and it has equally unstable constitutional and conceptual foundations and that it leaves much uncertainty regarding the actual legal and political limitations arising from EU human rights law. ${ }^{51}$ The value-based evaluation from Williams is particularly condemning. He argued that the causes of the shortcomings of the system of human rights protection in the EU must be found inside the EU polity and that these are together responsible for distorting the system by giving more weight to its institutional priorities than to its substantive, value-generating aspects. ${ }^{52}$

47 See Andrew Williams, 'Promoting Justice after Lisbon: Groundwork for a New Philosophy of EU Law' 201030 OJLS 663, 663; Douglas-Scott, 'The European Union' (n 8) 649.

48 See Douglas-Scott, 'Fundamental Rights' (n 9) 289-290.

49 Coppel and O’Neill (n 6) 670, 685-686.

50 See Joseph H.H. Weiler and Nicholas J.S Lockhart, “Taking Rights Seriously" Seriously: the European Court and its Fundamental Rights Jurisprudence - Part I' (1995) 32 CMLRev 51, 69-72.

51 Andrew Williams, The Ethos of Europe (CUP 2010) 115 and 267.

52 Ibid 152-153. See also Williams (n 13) 160 and Ian Ward, The Margins of European Law (Palgrave 1996) 151. 
Primarily, these criticisms find faults in the judicial character of EU human rights law and disagree with the interpretative practices followed by EU courts. Indeed, the contingency of the judicially developed body of law, ${ }^{53}$ the multiple and complex rationales for the judicial protection of human rights in the EU polity and context-influenced diversity of interpretative streams in the jurisprudence may lend a sense of incompleteness, incoherence and inconsistency to the law. ${ }^{54}$ Critical evaluations of the performance of EU courts in this domain must, however, take into account that the protection of human rights needed to be secured in the difficult constitutional and governance terrain of the EU and that their task, although they enjoyed the support of a broad jurisdictional clause, was in many ways novel. The protection of human rights in the EU required the anchoring of a novel legal principle, and the EU Court, engaged in the constitutional calibration of the EU legal order and the role of law in the operation of the EU polity, faced multiple demands arising from the constitutional and governance context. Its busy agenda included constitutional identity-building, using law to enhance the legitimacy of EU policies, introducing rule of law requirements against EU action, ensuring the protection of individuals against the use of public powers at the European and national levels, and introducing a robust expectation of effectiveness into the law and governance in the EU. Today, the demand for the jurisprudence to respond to a similarly diverse set of considerations remains similar.

This book aims to contribute to the critical evaluation of the EU jurisprudence by revealing the complex ways in which judicial interpretation is entangled with considerations arising from the EU constitutional and governance context. It discusses the multiple engagements of human rights law in the EU and argues that the jurisprudence must be understood through its dominant characteristic which is its complexity. It regards single-factor characterizations of the law as insufficiently formulated. They fail to appreciate the context in which EU human rights operate and the resulting character of the law. The book proposes a more rounded and better balanced image which views EU human rights law as breathing together with its broader and immediate interpretative environment. EU courts apply interpretative practices which determine the role

53 See in this regard concerning EU human rights law, Bruno de Witte, 'The Past and Future Role of the European Court of Justice in the Protection of Human Rights' in Philip Alston (ed.) The EU and Human Rights (OUP 1999) 870.

See Besselink (n 38) 636. 
and application of human rights in the EU with reference to considerations (agendas, interests, priorities, etc.) following from the constitutional and governance framework of the EU polity. The jurisprudence recognizes conventional and unconventional applications of human rights in the EU, as they follow from the context, for instance from the multi-tiered EU rule of law principle, and defines the location of human rights by determining the boundaries of the human rights jurisdiction of EU courts vis-á-vis the parallel constitutional authorities located internally and externally. In its different interpretative environments, as it also follows from the conceptual foundation provided by the rule of law in the EU, human rights could be applied to discharge the conventional task of constraining EU and Member State action and/or to perform the unconventional task of contributing to the constitution and development of the EU polity and constitutional order. The limitations of EU human rights law are also determined by its context in the course of applying the interpretative practice of judicial deference to EU constitutional, legislative and administrative power, to authority and discretion in the Member States, and to the authority of the ECHR.

The link between judicial interpretation and context enables identifying the concrete pathways and limitations the constitutional and governance context appears to provide, as indicated just above, for the law of human rights in the EU. There are multiple pathways and limitations, and they all follow from the interpretative internalization of considerations emerging from the context. It also suggests that EU human rights law engages in consolidative and mediatory applications. The creation and protection of human rights, the autonomy and constitutional manoeuvrability they offer, and the qualities and requirements they impose on EU governance have the effect of consolidating the EU constitutional system, in particular in relation to its constituents, and its boundaries. In this process, the jurisprudence is required to mediate between its parallel applications in the EU polity and reconcile the competing interests and rights recognized in the different constructions of EU governance. The exposure of the law to considerations arising from its context has a far-reaching consequence for the jurisprudence. Because the fundamental dilemmas of the EU constitutional and governance framework are addressed and resolved in the interpretation of human rights before EU courts, EU human rights law is placed in the heart of the development and the operation of the EU constitutional system. That responsibility requires a responsive and agile body of law capable of functioning in a difficult constitutional and governance environment. 